varying the width of the image results in a change in illumination, and the wider the image the poorer the contrast and the less clear the image definition. These two problems are by no means trivial. Perception of size is influenced by contrast between foreground and background (Goldstein, 1980), and clarity of outline in turn affects contrast. Clearly these factors need to be properly controlled in research concerned with perception of body size.

It is likely that the method of assessment reported by Touyz and colleagues will be adopted by other researchers in this field. Should this be the case, equipment should be employed which is not susceptible to the illumination problems highlighted. We have found also that the problem can be overcome electronically be coupling the image control to a source of illumination so that contrast and definition remain constant.

Melanie TAYLOR

JOHN BALDWIN

University of Cambridge,

PeTER COOPER

Department of Experimental Psychology,

Downing Street, Cambridge CB2 $3 E B$

References

Goldstein, E. B. (1980) Sensation and Perception. Belmont, California: Wadsworth.

SzMUKLeR, G. (1984) Body image disturbance in anorexia nervosa. British Journal of Psychiatry, 144, 553.

Touyz, S. W., Beumont, P. J. V., Collins, J. K., McCabe, M. \&

JUPP, P. (1984) Body shape perception and its disturbance in anorexia nervosa. British Journal of Psychiatry, 144, 167-171.

\section{DISORDERS WITH OVERVALUED IDEAS}

DEAR SIR,

McKenna's review article (Journal, December $1984,145,579-585$ ) with the above title contributes some useful points towards defining the nature of the belief, in dysmorphophobia, although he omits to state that the excessive concern with unsightly appearance occurs in a person of normal appearance.

The nature of the belief is rightly described as an overvalued idea. But many of the past studies he mentions fail to specify this view (Thomas, 1984), so that in such series the belief could be a delusionlike idea or a primary delusion (Jaspers, 1946). The latter is said to be diagnostic of schizophrenia and the former occurs in all types of psychoses (Fish, 1967), so it comes as no surprise to find high rates of schizophrenia. depression, personality disorder and severe neurosis in these populations.

The view that dysmorphophobia may be a symptom of an underlying disease is indisputable on clinical grounds, but $40 \%$ of the patients do not have underlying classifiable psychiatric illness (Thomas, 1984). I suggest that the term dysmorphophobia be reserved for such patients and that secondary or symptomatic dysmorphophobia should be used when other mental illness is responsible.

Christopher S. ThOMAS

Department of Psychological Medicine,

King's College Hospital,

Denmark Hill, London SE5 9RS

\section{References}

Fish, F. (1967) Disorders of thought and speech. In Fish's Clinical Psychopathology, (ed. M. Hamilton). Bristol: John Wright.

JASPERS, KARL (1946) Delusion and awareness of reality. In General Psychopathology 7th Edition. (Translated 1963 by S. Hoenig \& M. Hamilton) Manchester: Manchester University Press.

Thomas, C. S. (1984) Dysmorphophobia: A question of definition. British Journal of Psychiatry, 144, 513-516.

\section{MOOD CHANGES AFTER CHILD BIRTH}

DEAR SIR

With regard to the paper by Kendell et al (Journal, December 1984, 145, 620-625), I note that those components of mood likely to cause distress to the patient in the first two weeks after childbirth which were measured in this study included depression, irritability, tearfulness and anxiety. In out study of 42 women during the first week after childbirth, using a modified form of P.S.E. (Cooper et al, 1977), we found the major features of mood disturbance to be: anxiety, depression, tension and worries, with other less important but significant variables being obsessionalism, less of concentration and listlessness. In this series of publications we have drawn attention to the close correlation between platelet MAO activity (George \& Wilson, 1980), serum prolactin (George et al, 1980) and maternal B-endorphin/B-lipotrophin (George \& Wilson, 1982) and these specific mood variables. These studies emphasise the importance of biochemical mediators in the presentation of early puerperal mood disturbance and offer a biochemical template in studying the puerperal specificity of these mood changes as discussed in Kendell's paper.

Queen Elizabeth Military Hospital, Woolwich, London SE18

\section{References}

Cooper, J. E., Copeland, J. R. M., Brown, G. W., Harris, T. \& Gouray, A. J. (1977) Further studies on interview training and inter-rater reliability of the Present State Examination. Psychological Medicine, 7, 517. 
George, A. J., Copeland, J. R. M. \& Wilson, K. C. M. (1980) Serum prolactin and the postnatal blues. British Journal of Pharmacology, 70, 101-102.

- \& WILSON, K. C. M. (1981) Monoamine oxidase activity and the puerperal blues syndrome. Journal of Psychosomatic Research, 25, 409-413.

_ (1982) Maternal B-endorphin/B-lipotrophin correlates with prolactin in the first postpartum week. Journal of Clinical Pharmocology, 14, 146-147.

\section{EXAMINING CHILDREN WHO ARE WARDS OF COURT}

DeAR Sir,

A physician referred an anorexic girl to me for treatment. I assessed her, confirmed the diagnosis and transferred her for treatment under my care in the children's ward. This necessary action almost caused the County Council to be in contempt of Court because this girl is a Ward of Court. About the same time, mention was made at a clinic meeting that a disturbed child could not be seen at the clinic because he was a Ward of Court and the Court would not allow such an examination.

These disturbing events made me seek advice from the County Solicitor and the Medical Protection Society. It seems that divorcing parents, who were contesting guardianship and access, tended to use psychiatric reports as ammunition against each other. The Court, in order to protect children from such unnecessary investigation ruled that "it is improper for a Ward of Court to be psychiatrically examined without the consent of the Court or of the Official Solicitor or the minor's guardian ad litem". Fortunately, it is subsequently clarified that "this does not interfere with the discretion of a parent having de facto custody to take a sick child to a doctor".

It therefore seems that the consent of the Court needs to be obtained before a child, who is a Ward of Court, can be seen by a pscyhiatrist. I understand this is not so if a child needs to be seen by any other specialist. Readers of this journal will be well aware of the difficulties that have to be overcome by parents in order to seek the advice of a child psychiatrist. It seems to me that such discrimination could be restricting the number of children who could benefit from psychiatric treatment and could therefore place at a disadvantage the very children that it sets out to protect. I would be very interested to hear if colleagues have had similar experiences, although of course it is very difficult for psychiatrists to be aware of how many children who need to be seen are not seen.

Child and Family Guidance Clinic,

Jason Maratos

56 Amersham Hill, High Wycombe HP13 6PQ

\section{CORRECTION}

DEAR SIR,

'Schizophrenic Patients Discharged from Hospital-A Follow-up Study'. Johnstone et al, Journal, December 1984, 586-590.

I regret that when this paper was published the majority of the corrections that we made at the proof stage were not incorporated. Most of these were relatively trivial grammatical and spelling errors, but I am afraid that there is one error which is seriously misleading and which I would like to bring to the attention of readers of the Journal: Page 589; column 1, paragraph 2-the first sentence reads: "The findings indicate that recovery from schizophrenia does not take place ..."

This is wrong-'does not' should have been replaced with 'may'. Perceptive readers I am sure will have noticed that there must be an error at this point in the article but I would like to be sure that there is no confusion over this issue and to make it clear that what we wanted to say is: "The findings indicate that recovery from schizophrenia may take place even in patients fulfilling the St. Louis criteria for that diagnosis".

Clinical Research Centre,

Eve C. Johnstone 